\title{
Performance of Maize Single-Cross Hybrids Evaluated on Acidic Soils
}

\author{
P.K. Dewi-Hayati ${ }^{\#}$, Sutoyo ${ }^{\#}$, A. Syarif*, T. Prasetyo ${ }^{1}$ \\ \# Plant Breeding section, Department of Agroecotechnology, \\ Faculty of Agriculture, Andalas University. Kampus Unand Limau Manih, Padang-25163 Indonesia \\ E-mail:pkdewihayati@yahoo.com,sutoyo@faperta.unand.ac.id \\ *Agronomy section, Department of Agroecotechnology, \\ Faculty of Agriculture, Andalas University. Kampus Unand Limau Manih, Padang-25163 Indonesia \\ E-mail: auzar_syarif@yahoo.com
}

${ }^{I}$ Department of Soil Science, Faculty of Agriculture, Andalas University. Kampus Unand Limau Manih, Padang-25163 Indonesia

Email: teguhbudiprasetyo@yahoo.co.id

\begin{abstract}
Soil acidity is one of a number of limiting factor of maize production. Planting maize hybrid varieties tolerant to acid soils along with the use of sustainable agronomic practices offers an effective solution for improving maize productivity on acidic soils. Thirty-six single-cross hybrids derived from a 9x9 diallel cross, nine parental inbred lines and two check varieties i.e. a commercial hybrid and a composite variety Sukmaraga were evaluated in 2013 on acid aluminum-toxic soil at Limau Manis Padang in a Randomized Complete Block design in order to evaluate and select maize hybrids for high yield potential in acid soils and tolerant to acid soils. Data were subjected to the analysis of variance using the Proc GLM of the SAS software, while analysis of diallel was conducted using DIALLEL-SAS05 software. Results showed that several hybrids which were progenies of crossess between acid soiltolerant or moderately acid soil-tolerant inbred lines revealed high grain yield on acidic soils. The hybrids also revealed high heterosis magnitudes and high and positive specific combining abilities, low yield reduction and stress sensitivity indices, while they revealed high relative yield and stress tolerance indices. Hence, it is suggested that these promising hybrids can be further evaluated in large scale locational trials on acidic soils.
\end{abstract}

Keywords — maize; single-cross hybrids; performance; acidic soils.

\section{INTRODUCTION}

This Acid soils which are classified as Ultisols and Oxisols occupy about 60 million hectares of land in Indonesia [17]. The soils have low $\mathrm{pH}$, low cation exchange capacities, high $\mathrm{Al}$ concentration and low basic cations, mainly $\mathrm{Ca}$ and/or $\mathrm{Mg}$. Among these complex factors, aluminum (Al) toxicity is being a major constraint of crop production on acidic soils, including maize, in which the yields are reported unsatisfactorily in the soils [15]. Most studies in the past have been carried out in correcting soil acidity problems by application of lime or organic materials. Despite their ability to overcome soil acidity problems, application of the soil amendments has a number of limitations in use [11], [16], [8]. Thus, planting high yielding maize hybrid varieties tolerant to acid soils along with the use of sustainable agronomic practices offers an effective strategy for improving productivity of maize on acidic soils.
The development of maize hybrids for high yielding and tolerant to acid soils requires the widely genetic variability of inbred lines as a candidate of superior parental lines. An extensive maize breeding programme has been initiated at University of Andalas since 2008. This study was the ongoing program carried out to select inbred lines tolerant to Al on acidic soils [2] and utilize them towards the production of acid soil tolerant maize hybrids.

Although many genetics and physiological tolerance to acid soil studies have been conducted, yield potential based on the value of the tolerance or sensitivity indices to stress is required to select genotypes tolerant to acid soil. Relative indices (RI) [12], [9], stress susceptibility/sensitivity indices (SSI) [6] and stress tolerance indices (STI) [5] have all been developed and employed for various stress conditions.

Relative indices have been used for comparing yield on stress and non-stress condition directly. The stress susceptibility indices (SSI) is a ratio of genotypic 
performance under stress and non-stress conditions. Genotypes with an SSI of less than a unit are stress tolerance, since their yield reduction in stress condition is smaller than the mean yield reduction of all genotypes. SSI were found to be more useful in discriminating tolerant genotypes. The stress tolerance indices (STI) have been used for comparing genotypic performance across environment condition. The objectives of this study were to evaluate the yield potential of single-cross hybrids from cross combination of 9x9 inbred lines and to select maize hybrids for high yield potential in acid soils and tolerant to acid soils.

\section{Methodology}

The research was carried out in September to March 2013 at the Faculty of Agriculture Farm Unit, University of Andalas, Limau Manih Padang. The genetic material used were the 36 single-cross hybrids obtained from a 9x9 diallel cross, the nine parental inbred lines and the two check varieties, i.e. Sukmaraga, a composite variety was reported as acid soil-tolerant variety [10] and one commercial hybrid variety. The nine inbred lines were derived from different source populations and selected based on their tolerance to acid soil, performance and yield potential on an optimum soil condition. All the inbred lines were crossed in all possible combinations to produce 36 single-cross hybrids. The experiment were arranged in a randomized complete block design with five replications, four replications were assigned to acid soil which was the naturally acidic soils, and the other one was assigned to acid soil ameliorated by ground magnesium limestone at the rate of $2 \mathrm{tha}^{-1}$.

Each genotype was planted as many as four 3-meter long rows with a spacing of $25 \mathrm{~cm} \mathrm{x} 75 \mathrm{~cm}$. Fertilizers were applied at the rate of $150 \mathrm{~kg} \mathrm{~N} \mathrm{ha}^{-1}, 120 \mathrm{~kg} \mathrm{P}_{2} \mathrm{O}^{5} \mathrm{ha}^{-1}$ and $100 \mathrm{~kg} \mathrm{~K}_{2} \mathrm{O} \mathrm{ha}^{-1}$ in the form of urea, SP36 and $\mathrm{KCl}$ at 14 days after planting. Urea is applied in split at 14 and 30 days after planting. The data analyzed was grain weight per plant after being converted to $14 \%$ moisture content.

Data were analyzed using the variance F test, whereas the mean comparisons were performed using Least Significant Difference at 5\% level of the Statistical Analysis System (SAS) computer software [14]. The diallel analysis was conducted following Griffing's Method 4 (one set of F1 progenies) using the DIALLEL-SAS05 software [20]. Heterosis is estimated as the percentage of superiority of the hybrid over its mid-parent value. Selection indices were calculated using grain yield on acid and limed soils with the following relationship.

$$
\begin{gathered}
\mathrm{RI}=\frac{Y s}{Y p} \\
\mathrm{SSI}=\frac{(Y p)(Y s)}{(\overline{Y p})^{2}} \\
S T I=\frac{\left[1-\frac{Y s}{Y p}\right]}{1-\frac{(\overline{Y s})}{(\overline{Y p})}}
\end{gathered}
$$

Ys and Yp are grain yield in acid and limed soil, respectively, while $\overline{\mathrm{Ys}}$ and $\overline{\mathrm{Y}} p$ are means of grain yield on acid and limed soil, respectively. Simple Pearson's correlations among grain yield on acid and limed soils, specific combining ability and selection indices were determined based on the formula suggested [7] and calculated using Proc Corr of SAS statistical software [14].

\section{RESUlTS AND DISCUSSION}

The soil used for evaluation was Ultisol with low soil $\mathrm{pH}$ and basic cations, while high aluminium concentration in the soil solution (Table 2). Application of limestone decreased exchangeable $\mathrm{Al}$, while that increased the basic cations and the soil $\mathrm{pH}$. The $\mathrm{pH}$ of limed soil still was classified as acidic, however the saturation of $\mathrm{Al}$ was low due to the increased of the cation bases. The grain yield of the hybrids on limed soil condition, consistently higher than that on acidic soils, indicating that the soil condition was considered optimum for growth and yield of maize. The grain yield in this study decreased with the increasing amount of exchangeable aluminum as represented by different replication. The reduction of grain yields in acid soil varied greatly within genotypes and acid soil conditions, ranging from 2.8 to $71 \%$.

TABLE I

SOIL CHEMICAL Properties

\begin{tabular}{|l|c|c|}
\hline Soil condition & Limed soil & Acid soil \\
\hline $\mathrm{pH}_{(\mathrm{H} 2 \mathrm{O})}(1: 1)$ & 5.2 & $3.8-4.3$ \\
\hline $\mathrm{CEC}\left(\mathrm{cmol}_{\mathrm{c}} \mathrm{kg}^{-1}\right)$ & 20.3 & $15.33-20.33$ \\
\hline $\mathrm{P}(\mathrm{ppm})$ & 4.3 & $2.73-4.03$ \\
\hline $\mathrm{Ca}\left(\mathrm{cmol}_{\mathrm{c}} \mathrm{kg}^{-1}\right)$ & 1.52 & $0.19-0.20$ \\
\hline $\mathrm{Mg}\left(\mathrm{cmol}_{\mathrm{c}} \mathrm{kg}^{-1}\right)$ & 0.55 & $0.34-0.44$ \\
\hline $\mathrm{K}\left(\mathrm{cmol}_{\mathrm{c}} \mathrm{kg}^{-1}\right)$ & 0.29 & $0.07-0.30$ \\
\hline $\mathrm{Na}\left(\mathrm{cmol}_{\mathrm{c}} \mathrm{kg}^{-1}\right)$ & 0.57 & $0.15-0.64$ \\
\hline $\mathrm{Al}\left(\mathrm{cmol}_{\mathrm{c}} \mathrm{kg}^{-1}\right)$ & 1.12 & $1.31-3.21$ \\
\hline $\mathrm{Al} \mathrm{saturation}(\%)$ & 0.22 & $0.38-0.67$ \\
\hline
\end{tabular}

The top ten high yielding hybrids in acid soil conditions out-yielded both the check varieties (Table 2). Eventhough the two check varieties produced high yield on limed soil, they produced low yield on acid soil, especially a commercial hybrid. It showed higher yield reduction compared to average yield reduction of hybrids, signifying that the hybrid is acidic soil sensitive. Unexpected result was found in Sukmaraga performance that produced low yield on acid soils. This was not consistent with the findings of [3] and [4] who reported that this variety gave comparable yield with high acidic soil tolerant hybrids evaluated on acidaluminium toxic soils in Malaysia.

High relative and stress tolerance indices indicate that genotypes are acid-soil tolerant, while high yield reduction and stress sensitivity indices indicate less tolerance of genotypes to acid soil. The high yielding hybrids revealed lower yield reduction and stress sensitivity indices, while they showed higher relative yield and stress tolerance indices compared to those of hybrid means (Table 3). Several hybrids that were marked with bold letter were also the hybrids that revealed high yield on limed soil. This indicates that the indirect selection for identifying superior hybrids for acid soil tolerance can be carried out on limed soil condition as also proposed by [1]. 
TABLE II

THE Top Ten HIgh YIELDING MAIZE Hybrids ON ACID SOIL AND THEIR YiELD ON LIMED SOIL AND SPECIFIC COMBINING ABILITIES

\begin{tabular}{|c|c|c|r|c|}
\hline \multirow{2}{*}{ Hybrid } & \multirow{2}{*}{ Parental line } & \multirow{2}{*}{ SCA } & \multicolumn{2}{|c|}{ Yield (g/plant) } \\
\cline { 4 - 5 } & & & limed soil & acid soil \\
\hline H8 & UA8 x UA1 & 8.3 & 112.8 & 80.4 \\
\hline H21 & UA9 x UA2 & $12.8^{*}$ & 111.2 & 78.0 \\
\hline H6 & UA6 x UA1 & $12.6^{*}$ & 116.8 & 76.0 \\
\hline H34 & UA7 x UA3 & $14.5^{*}$ & 90.7 & 75.0 \\
\hline H13 & UA3 x UA2 & 6.0 & 106.5 & 74.7 \\
\hline H35 & UA8 x UA3 & 2.8 & 100.6 & 74.1 \\
\hline H31 & UA4 x UA3 & $17.0^{*}$ & 101.8 & 72.9 \\
\hline H53 & UA8 x UA6 & 1.6 & 91.4 & 72.3 \\
\hline H51 & UA9 x UA5 & $18.4^{*}$ & 96.7 & 71.3 \\
\hline H16 & UA6 x UA2 & 2.8 & 92.5 & 70.9 \\
\hline Smrg & & & 100.3 & 60.4 \\
\hline HC1 & & & 109.8 & 50.7 \\
\hline Means & & n.a. & 91.62 & 61.4 \\
\hline LSD & & 9.1 & n.a. & 9.04 \\
\hline
\end{tabular}

* significant at $\alpha_{0.05}$

n.a. = not available

High relative and stress tolerance indices indicate that genotypes are acid-soil tolerant, while high yield reduction and stress sensitivity indices indicate less tolerance of genotypes to acid soil. The high yielding hybrids revealed lower yield reduction and stress sensitivity indices, while they showed higher relative yield and stress tolerance indices compared to those of hybrid means (Table 3). Several hybrids that were marked with bold letter were also the hybrids that revealed high yield on limed soil. This indicates that the indirect selection for identifying superior hybrids for acid soil tolerance can be carried out on limed soil condition as also proposed by [1].

TABLE III

The Top Ten High Yielding MaIze Hybrids On ACID SoIL, TheIR YIELD REDUCTION, RI, SSI AND STI VALUES

\begin{tabular}{|c|c|c|c|c|}
\hline Hybrid & $\begin{array}{c}\text { Yield Reduction } \\
(\%)\end{array}$ & RI $^{¥}$ & SSI $^{¥}$ & STI $^{¥}$ \\
\hline H8 & 28.7 & 0.71 & 0.69 & 1.08 \\
\hline H21 & 29.9 & 0.70 & 0.69 & 1.03 \\
\hline H6 & 34.9 & 0.65 & 0.89 & 1.06 \\
\hline H34 & 17.3 & 0.83 & 0.40 & 0.81 \\
\hline H13 & 29.8 & 0.70 & 0.67 & 0.95 \\
\hline H35 & 26.3 & 0.74 & 0.66 & 0.89 \\
\hline H31 & 28.4 & 0.72 & 0.72 & 0.88 \\
\hline H53 & 20.9 & 0.79 & 0.54 & 0.79 \\
\hline H51 & 26.2 & 0.74 & 0.67 & 0.82 \\
\hline H16 & 23.3 & 0.77 & 0.51 & 0.78 \\
\hline Smrg & 39.8 & 0.60 & 1.10 & 0.72 \\
\hline HC1 & 53.8 & 0.46 & 1.50 & 0.66 \\
\hline Means & 0.32 & 0.68 & 0.82 & 0.68 \\
\hline LSD $(0.05)$ & 9.2 & 0.09 & 0.37 & 0.12 \\
\hline
\end{tabular}

${ }^{*} \mathrm{RI}=$ Relative Indices, SSI $=$ Stress Sensitivity Index,

STI $=$ Stress Tolerance Index

Positive strong relationships was found between yield on acid soil and yield on limed soil, specific combining ability, relative indices and stress tolerance indices (Table 4). In contrast, negative relationship was found between yield on acid soil and yield reduction and stress sensitivity indices. Hybrids which showed tolerance to acid soil revealed high yields on acid or limed soils and high specific combining ability values. Among selection indices, relative indices was significantly and negatively correlated with stress sensitivity indices, however it was not correlated with stress tolerant indices. There is no relationship between stress tolerance indices with stress sensitivity indices in this study. Specific combining ability was highly correlated with stress tolerance indices, indicating that stress tolerant indices was useful to select superior hybrids on acid soils.

TABLE IV

COEFFICIENT OF CORRELATIONS BETWEen YIELD ON ACID AND LIMED SOILS, SPECIFIC COMBINING ABILITY AND SELECTION INDICES

\begin{tabular}{|l|c|c|c|c|c|c|}
\hline & YLS & SCA & YR & RI & SSI & STI \\
\hline YAS & $0.68^{* *}$ & $0.80^{* *}$ & $-0.45^{* *}$ & $0.45^{* *}$ & $-0.44^{* *}$ & $0.93^{* *}$ \\
\hline YLS & & $0.63^{* *}$ & $0.33^{*}$ & $-0.33^{*}$ & $0.33^{*}$ & $0.89^{*}$ \\
\hline SCA & & & -0.25 & 0.25 & -0.25 & $0.78^{* *}$ \\
\hline YR & & & & $-1.0^{* *}$ & $0.97^{* *}$ & -0.12 \\
\hline RI & & & & & $-0.97^{*}$ & 0.12 \\
\hline SSI & & & & & & -0.12 \\
\hline
\end{tabular}

*, ** significant at $\alpha_{0.05}$ and $\alpha_{0.01}$

YLS=yield on limed soil, YAS=yield on acid soil, SCA=specific combining ability, YR=yield reduction, RI=relative indices, SSI=stress susceptibility indices, and STI=stress tolerance indices

With regards of heterosis (data was not shown), the hybrids exhibited significant and high heterosis estimates for grain yield, indicating that the hybrids performed higher grain yield over their mid-parent values. The heterosis estimates for grain yield on acid soils were consistently higher than those on limed soils. The higher magnitudes of heterosis under acidic soil (stress condition) than those under limed soil (non-stress condition) were in agreement with the findings of [1] and [19]. Under high stress environment, such as high soil acidity, the performances of parental lines were poor and this condition resulted in too high magnitude of heterosis.

Besides the hybrids exhibited high heterosis estimates, several hybrids, i.e. hybrids H6, H21, H34, H31 and H51, exhibited high and positive specific combining ability (SCA). Some hybrids were progenies of crosses among acid soiltolerant or moderately tolerant inbred lines [2]. Their parental inbred lines were composite variety Sukmaraga which was reported as acid soil tolerant variety.

A quadrant model which distinguishes the hybrids based on their tolerance to acidic soil and yield potential on acid soils was developed according to [13] and [9]. The relative yields were plotted along the $\mathrm{Y}$-axis, while yields on acidic soils were plotted along the $\mathrm{X}$-axis. The vertical line corresponds to the average yield of the best one-third of the hybrids on acidic soils, while the horizontal line corresponds to the average relative yield consisting of the best one-third of the hybrids (Fig. 1).

Most of the hybrids were in the quadrant IV and classified as tolerant to acid soil, however they had low yielding potential on acid soils. Both two check varieties were in the quadrant I and classified as sensitive to acid soil and had low yielding potential on acid soil. Conversely, hybrids H34, $\mathrm{H} 35, \mathrm{H} 13, \mathrm{H} 21$ and $\mathrm{H} 8$ were found to be tolerant to acidic soils and had high yielding potential on acidic soils 
(Quadrant III). Only hybrid H34 was found to exhibit high and positive SCA for yield potential on acid soil.

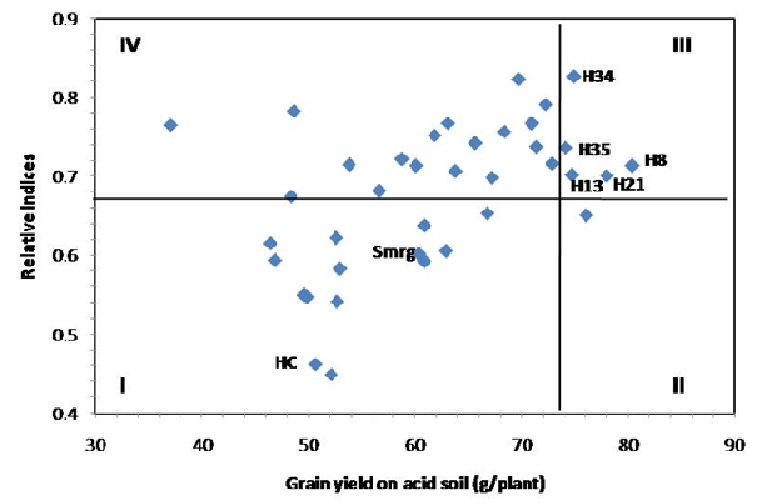

Fig. 1. Relationship between relative yield and yield on acidic soils of 36 maize hybrids and two check varieties

Distinguishing of hybrids based on their yield potential on acidic and limed soils as suggested by [19] were able to identify hybrids that had high yield potential both on acidic and limed soils (Fig.2). Hybrids in Quadrant I exhibits lowyielding capacity in both soil conditions, while the Quadrant II and IV consist of hybrids with high-yielding capacity on limed and acid soils, respectively, including the two check varieties which are classified as high-yielding capacity on limed soils. The hybrids in the Quadrant III show highyielding capacity in both soil conditions, including hybrids H8, H21 and H6 which revealed high STI value. STI was more effective in identifying genotypes that perform well under both stress and non-stress conditions [18]. Among the hybrids within the Quadrant III Fig. 1, hybrid H34 was not classified as hybrid with high yielding potential in both acid and limed soil conditions.

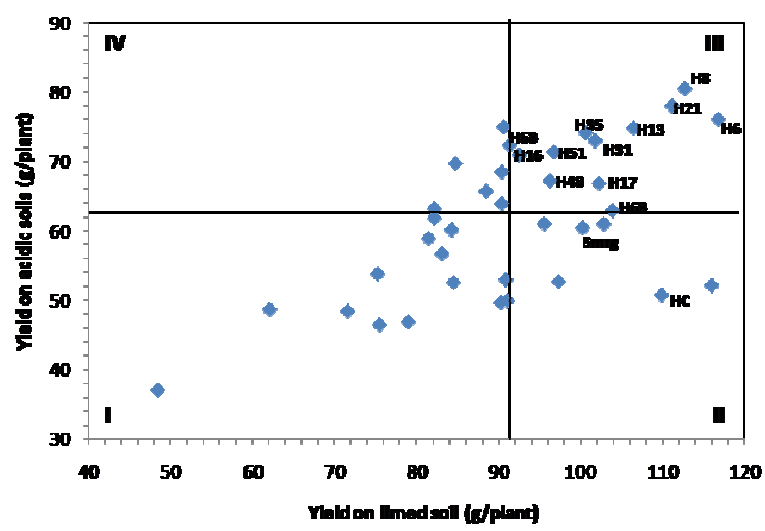

Fig. 1. Relationship between grain yield of 36 maize hybrids and two check varieties on acidic and limed soils

\section{CONCLUSIONS}

This study has revealed hybrids that have high genetic potential for tolerance to acid soils. Hybrids H6, H21, H34, H31 and H51 were identified as hybrids with good specific combining ability for yield on acid soil. Hybrid H34 was consistently found to be tolerant to acidic soils and possess high yielding potential on acidic soils. Thus, it is suggested that all these promising hybrids can be further evaluated in large scale locational trials on acidic soils.

\section{ACKNOWLEDGMENT}

The authors would like to thank Directorate General of Higher Education of Indonesia through research grant. The authors also express their thanks to Mr. Tatang Subianto for his excellent technical assistance.

\section{REFERENCES}

[1] Betrán, F.J., J.M. Ribaut, D. Beck and D. Gonzales de León, "Genetic diversity, specific combining ability and heterosis in tropical maize under stress and nonstress environments," Crop Sci, vol 43, pp.797-806, 2003.

[2] Dewi-Hayati, P.K. and Armansyah, "Evaluation of aluminum tolerance on maize inbred lines derived from sukmaraga variety," $J$. Agrotropical, vol.1(2), pp.1-9, 2011.

[3] Dewi-Hayati P.K., G.B. Saleh, J. Shamshuddin and S. Napis, "Evaluation and selection of maize hybrids for tolerance to acid soils," in Proc. International Agriculture Congress, 2009, Selangor, Malaysia, p.80-82.

[4] Dewi-Hayati P.K., G.B. Saleh, J. Shamshuddin and S. Napis, "Yield potential of tropical maize hybrids in acid soils", in Proc. International Conference on Food Security during Challenging Times, 2010, Selangor, Malaysia. p.172-175.

[5] Fernandez, G.C.J., "Effective selection criteria for assessing stress tolerance" in Proc. International Symposium on Adaptation of Vegetables and Other Food Crops in Temperature and Water Stress. 1992, Tainan, Taiwan, p.257-270..

[6] Fischer, R.A. and R. Maurer, "Drought resistance in spring wheat cultivars. I: Grain yield response", Aust. J. Agric. Res., vol 29, pp. 897-907, 1978.

[7] Gomez, K.W. and A.A. Gomez. Statistical Procedures for Agricultural Research. NY, USA:John Wiley \& Sons Inc., 1984.

[8] Hede, A.R., B. Skovmand, J.M. Ribaut, D. Gonzáles-de-León and O. Stølen, "Evaluation of aluminum tolerance in a spring rye collection by hydroponic screening," Plant Breed., vol.121, pp.241-248, 2002.

[9] Howeler, R.H., Plant-Soil Interactions at Low pH.. R.J. Wright, V.C. Valigar and R.P. Murrmann, Ed., Dordrecht:bKluwer Aca Pub., 1991.

[10] ICERI, Innovation of Maize Technology. Indonesian Cereals Research Institute. Maros, Sulawesi. Indonesia: ICERI, 2004.

[11] Kamprath, E.J., "Potential detrimental effects from liming highly weathered soils to neutrality," Soil Crop Sci. Soc. Florida Proc., vol.31, pp.200-204,1971.

[12] Kasim, F. \& C.E. Wassom, "Genotypic response of corn to aluminum stress. I. Seedling test for measuring aluminum tolerance in nutrient solutions", Indonesian J. of Crop Sci., vol. 5(2), pp.41-51, 1990.

[13] Sangalang, J.B. and J.C. Bouwkamp,"Selection of sweet potato for tolerance to aluminum toxicity: Screening procedures and field test, J.Amer.Soc.Hort. Sci. vol.113, pp.277-281, 1988.

[14] SAS/STAT ${ }^{\circledR}$ User's Guide. Ver. 9.1. SAS Institute Inc. Cary, NC., 2003.

[15] Shamshuddin, J., I. Che Fauziah and H.A.H. Sharifuddin, "Effects of limestone and gypsum applications to a Malaysian Ultisol on soil solution composition and yields of maize and groundnut", Plant and Soil, vol.134, pp.45-52, 1991.

[16] Shamshuddin, J., H.A.H. Sharifuddin and L.C. Bell, "Longevity of ground magnesium limestone applied to an Ultisol", Commun. Soil Sci. and Plant Anal., vol. 26(9\&10), pp.1299-1313, 1998.

[17] Subagyo, H., N. Suharta, and A.B. Siswanto. Tanah-Tanah Pertanian di Indonesia. Pusat Penelitian Tanah dan Agroklimat, Bogor, Indonesia. 2000.

[18] Sio-Se Mardeh A., A. Ahmadi, K. Poustini and V. Mohammadi, "Evaluation of drought resistance indices under various environmental conditions". Field Crops Res, vol.98, pp.222-229, 2006 .

[19] Welcker, C., C. Thé, B. Andréau, C. De Leon, S.N. Parentoni, J. Bernal, J. Félicité. C. Zonkeng, F. Salazar, L. Narro, A. Charcosset and W.J. Horst, "Heterosis and combining ability for maize adaptation to tropical acid soils: Implications for future breeding strategies", Crop Sci., vol.45, pp.2405-2413, 2005.

[20] Zhang, Y., M.S. Kang and K.R. Lamkey, "DIALLEL-SAS05: A comprehensive program for Griffing's and Gardner-Eberhart analyses", Agron. J., vol.97, pp. 1097-1106, 2005. 